\title{
ПОРІВНЯЛЬНА КАРПОЛОГІЯ ВИДІВ РОДУ SCUTELLARIA L. (LAMIACEAE)
}

\author{
Коваль І. В., Вакуленко Т. Б.
}

\section{ВСТУП}

Ботанічними садами здійснюються фундаментальні й прикладні дослідження в галузі інтродукції, акліматизації та селекції рослин; збираються та утримуються колекції з метою збереження біологічного різноманіття та охорони рослинного світу ${ }^{1}$.

Scutellaria L. (Шоломниця) - великий і поліморфний рід, належить до порядку Lamiales, родини Lamiaceae, підродини Scutellarioidea й поділяється на підроди, які своєю чергою розділено на секції, а ті - на ряди ${ }^{2}$. Під однією видовою назвою можуть бути об'єднані декілька географічних $\mathrm{pac}^{3}$, і це $\epsilon$ цікавим предметом для подальших досліджень. Рід Scutellaria L. відмінний від більшості представників родини Lamiaceae, які належать до ефіроолійних рослин. У світовій флорі налічується від 350 до 425 видів цього роду ${ }^{4}$.

В Україні зростає дев'ять видів шоломниць - S. albida L., S. altissima L., S. creticola Juz., S. dubia Taliev et Sirj., S. galericulata L., S. hastifolia L., S. orientalis L., S. verna Bess., S. woronowii Juz ${ }^{3}$, - тобто становлять приблизно 2,1-2,5\% світового різноманіття. Види роду належать до лікарських рослин і застосовуються як у народній, так і в офіційній медицині. Чотири види флори України (S. altissima, S. creticola, S. galericulata, $S$. orientalis) використовуються в народній медицині ${ }^{5}$. Але тільки засоби на основі шоломниці байкальської (S. baicalensis Georgi) широко використовуються в офіційній медицині ${ }^{6,7,8}$. Цей вид природно зростає в Монголії, Китаї, Японії, Східному Сибіру й на Далекому Сході

\footnotetext{
1 Джуренко Н.I. Оцінка генетичних ресурсів колекційного фонду лікарських рослин. Фактори експериментальної еволюиї організмів / Н.І. Джуренко, О.П. Паламарчук, С.О. Четверня, І.В. Коваль. 2019. Т. 24. C. 254-258. DOI: https://doi.org/10.7124/FEEO.v24.1111.

${ }^{2}$ Флора СССР Т. 20 / ред. Б.К. Шишкин, С.В. Юзепчук. Москва-Ленинград : Из-во Академии наук СССР, 1954. С. 71-225.

${ }^{3}$ Определитель высших растений Украины / Д.Н. Доброчаева, М.И. Котов, Ю.Н. Прокудин и др. 1 изд. стереот. Киев : Фитосоциоцентр, 1999. 548 с.

${ }^{4}$ Ranjba M., Mahmoudi C. Chromosome numbers and biogeography of the genus Scutellaria L. (Lamiaceae). Caryologia. No. 66. 2013. P. 205-214. DOI: 10.1080/00087114.2013.821840.

5 Мінарченко В.М. Лікарські судинні рослини України (медичне та ресурсне значення) : монографія. Київ : Фітосоціоцентр, 2005. С. 211.

${ }^{6}$ Державна фармакопея України. URL: https://www.pharmencyclopedia.com.ua/article/2462/ derzhavnafarmakopeya-ukraini.

${ }^{7}$ Патентный поиск в РФ. URL: http://www.freepatent.ru/patents/2121357.

${ }^{8}$ The Sloan Kettering Institute (SKI). URL: https://www.mskcc.org/cancer-care/integrative-medicine/ herbs/scutellaria-baicalensis.
} 
Росії, а в Україні культивується. 3 метою ширшого використання в медицині всебічно вивчалась шоломниця звичайна (S. galericulata) ${ }^{9}$.

Багато видів шоломниць культивуються як декоративні рослини. Актуальним питанням $є$ інтродукція та дослідження видів цього роду для уточнення систематики й морфології видів, наявності в них біологічно активних речовин для їхнього поліфункціонального застосування.

Карпологічні ознаки видів рослин вважаються досить константними, що зумовлює широке їх використання для розв'язання спірних питань систематики й філогенії таксонів різного рівня ${ }^{10,11,12,13}$. Застосування методів електронної мікроскопії дозволяє значно розширити перелік діагностичних ознак, що мають високу стабільність, важливу для ідентифікації видів i реконструкції шляхів їхньої еволюції14. Карпологічні дослідження видів роду Scutellaria L. фрагментарні, в літературі зустрічаються лише короткі неповні описи ${ }^{15}$.

Плід у губоцвітих (Lamiaceae) - ценобій (coenobium) - різновид ценокарпної роздрібної коробочки, що утворюється 3 двочленного двогніздого гінецею. На ранніх етапах розвитку в кожному гнізді закладається перегородка, завдяки чому до моменту запилення зав’язь розділена на чотири гнізда, кожне з яких містить один насіннєвий зародок. Надалі розвивається чотиринасінний плід, що складається 3 чотирьох половинок двох мерикарпіїв. Кожна половинка по суті $\epsilon$ напівмерикарпієм, який для губоцвітих отримав спеціальну назву - ерем (eremus). Проте в літературі цю назву використовують рідко, описуючи плоди губоцвітих як горішки, 3 чим ми не погоджуємось, оскільки горішки розвиваються 3 апокарпного гінецею ${ }^{16}$. Ценобій розміщений на дні чашечки, яка не опадає, і повністю нею прихований. Оскільки ценобій під час дозрівання швидко розпадається, діагностичного

\footnotetext{
9 Дудецкая Н.А. Фармакогностическое изучение травы шлемника обыкновенного Scutellaria galericulata L. : автореф. дисс. ... канд. фарм. наук : 14.04 .02 «Фармацевтическая химия, фармакогнозия»; ГБОУ ВПО Санкт-Петербург гос. хим.-фарм. академия Минздравсоцразвития России. Санкт-Петербург, $2011.20 \mathrm{c}$.

${ }^{10}$ Каден Н.Н. Основы эволюционной морфологии плодов : дис. ... д-ра биол. наук. Москва :1964. $676 \mathrm{c}$.

${ }_{11}$ Левина Р.Е. Репродуктивная биология семенных растений : обзор проблемы. Москва : Наука, $1981.96 \mathrm{c}$.

${ }_{12}$ Меликян А.П., Бобров А.В., Романов М.С. Морфогенез плодов Magnoliophyta. Москва : URSS, 2008. $317 \mathrm{c}$.

${ }^{13}$ Takhtajan A.I. Diversity and classification of flowering plants. New York : Columbia University Press, 1997. $643 \mathrm{p}$.

14 Футорна О.А., Жигалова С.Л. Ультраструктура поверхні насінин видів роду Gladiolus L. (Iridaceae Juss.) флори України. Чорноморський ботанічний журнал. 2014. № 10 (1). C. 15-25. DOI: $10.14255 / 2308-9628 / 14.101 / 2$.

${ }_{15}$ Червона книга України. Рослинний світ / під заг. ред. Я.П. Дідуха. Київ : Глобалконсалтинг, 2009. $912 \mathrm{c}$.

${ }^{16}$ Артюшенко 3.Т., Федоров А.А. Атлас по описательной морфологии высших растений. Плод. Ленинград : Наука, 1986. 392 с.
} 
значення в разі вивчення карпології губоцвітих набувають морфологічні особливості лише еремів.

Мета дослідження - проаналізувати видову різноманітність роду Scutellaria L. в Україні й світі й визначити перспективи інтродукції; вивчити карпологічні відмінності й особливості ультраструктури поверхні деяких видів роду, оцінити їхнє діагностичне значення та визначити можливості використання для систематики й ідентифікації таксонів.

Методи. Для дослідження використовували зрілі ереми чотирьох видів роду Scutellaria L.: S. albida, S. altissima, S. baicalensis, S. creticola, отримані з Дослідної станції лікарських рослин Інституту агроекології і природокористування Національної академії аграрних наук. Гербарні зразки вивчались у гербарії Національного ботанічного саду імені M.M. Гришка Національної академії наук України (KWHA). Макроморфологічні особливості вивчались за допомогою бінокулярного мікроскопа "Stemmi-2000", описи карпологічних ознак наведені за загальноприйнятими методиками, обробка цифрових даних здійснена в програмі “Axio Vision”.

Зразки плодів для дослідження методом растрової електронної мікроскопії мали декілька етапів попередньої підготовки. Відібрані зразки наклеювали нітролаком на мідні пластинки. Напилення вуглецем проводили на столику 3 нахилом та обертанням методом вакуумного термічного випаровування вакуумного універсального поста ВУП-5М, AT SELMI, Суми, Україна. Напилення платиною проводили за допомогою пристрою іонно-плазмового травлення JFC-1600, JEOL, Токіо, Японія. Ультраструктуру поверхні вивчали за допомогою растрового електронного мікроскопа JSM-6700F, JEOL, Токіо, Японія в режимі вторинної електронної емісії.

Для характеристики ультраструктури оплодня застосована термінологія W. Barthlott ${ }^{17} \mathrm{i}$ W. Stern ${ }^{18}$, згідно 3 якою розрізняють первинну й вторинну структуру. Первинна структура визначається макроморфологією плодів і насіння (форма клітин епідерми, кривизна, висота, товщина й рельєф їхніх периклінальних та антиклінальних стінок, характер опушення тощо). Вторинна структура характеризує мікроморфологію та визначається скульптурою кутикули.

\section{1. Ботанічний опис досліджуваних видів}

S. albida має повзуче, звивисте, світло-коричневе кореневище. Стебла 23-50 см заввишки, прямі або злегка звивисті, частіше гіллясті, з догори спрямованими, супротивно акроскопними гілками, тупо чотиригранні,

\footnotetext{
${ }^{17}$ Barthlott W. Epidermal and seed surface characters of plants: systematic applicability and some evolutionary aspects. Nord. J. Bot. 1981. No. 1 (3). P. 345-355.

${ }^{18}$ Stern W.T. Botanical Latin. Oxford, 1992. $612 \mathrm{p}$.
} 
густо вкриті вигнутими, донизу відхиленими волосками. Листки $2-5$ см завдовжки, 1-4 см завширшки, на довгих черешках, густо вкритих короткими відхиленими волосками. Листки широкояйцеподібні, зі зрізаною або слабо серцеподібною основою, тупі, з 3-12 неглибокими тупими або округленими зубцями 3 кожного боку, вкриті з обох боків, але зісподу набагато густіше, дрібними відхиленими волосками. Приквіткові листки на довгих черешках, широко еліптичні або яйцеподібно-ланцетні, на верхівці закруглені, 3 невеликим гострим кінцем або загострені, цілокраї, помітно довші за чашечку, під час цвітіння досягають або перевищують довжину квіток. Суцвіття 5-16 см завдовжки, спочатку стисле, потім подовжується, але не пухке. Квітконіжка 2-3 (4) мм завдовжки. Чашечка 3-4 мм завдовжки, вкрита назад відхиленими, нечисленними, довгими волосками й численними залозками, при плодах 7-8 мм завдовжки. Віночок білуватий, до 15 мм завдовжки. Цвіте в червні-серпні. Зростає в лісах, по берегах річок, кам'янистих осипах, на вапняках, зрідка в гірському Кримі. Досліджений зразок S. albida: «Грузинская CСР, Гагрский р-н, дорога на озеро Рица, на опушке лиственного леса в ущелье Юпшара, редко», 17 вересня 1959 p., Leg. Det. C.C. Харкевич (KWHA) (Рис. 1).

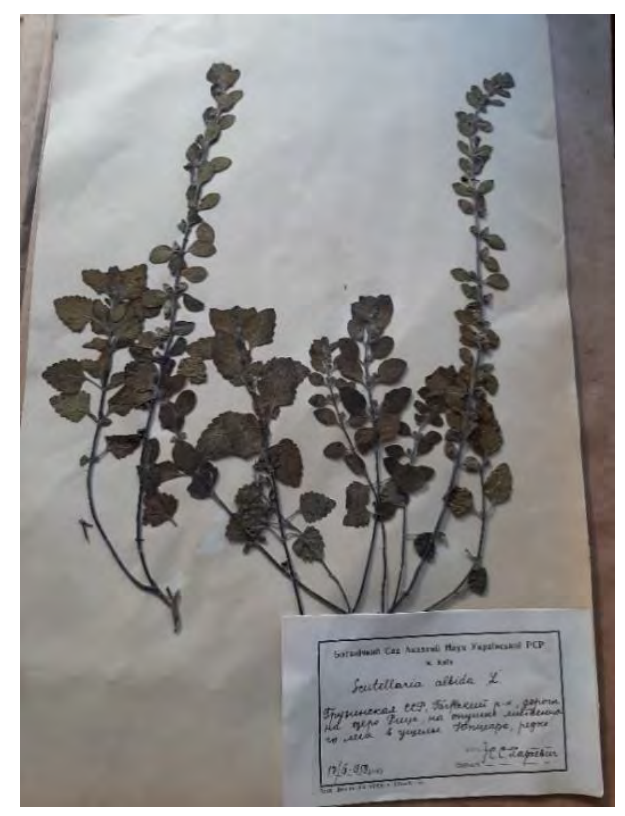

\section{Рис. 1. Гербарії досліджуваних рослин роду Scutellaria L. :S. albida}

S. altissima має вузлувате кореневище. Стебла 25-100 см заввишки, прямі, прості або з прямостоячими супротивно розташованими гілками, чотиригранні, вкриті дрібними, короткими залозистими волосками, які відхилені догори (особливо в суцвітті). Листки 4-8 см завдовжки, 2,5-7 cм завширшки, на довгих черешках. Пластинка листка 
яйцеподібна, зі зрізаною або серцеподібною основою, тупою або загостреною верхівкою, 3 (3) 6-12 великими, тупими, городчастими зубцями 3 кожного боку. Листки зверху голі або коротко-волосисті, зісподу щільно зігнуто-волосисті (особливо по жилках). Приквіткові листки на коротких черешках, (широко) яйцеподібні, гострі, цілокраї, трохи довші за чашечку або майже дорівнюють ій. Суцвіття (негусті однобічні китиці) до 30 см завдовжки. Квітки 13-18 мм завдовжки, на квітконіжках до 3 мм завдовжки. Чашечка вигнута, вкрита м'якими залозистими волосками, часто фіолетового кольору. Віночок із колінноувігнутою в нижній частині трубкою, залозисто-волосистий. Верхня губа блакитно-біла $з$ фіолетово-синьою спинкою, довша за жовтуватобілувату нижню губу. Цвіте в травні-червні. Зростає в Лісостепу, Степу, розсіяна в Криму у світлих листяних лісах, чагарниках, на схилах луків. Досліджений зразок S. altissima: «УССР, ЦРБС АН УССР, «западная дубрава» инвентр. № 217323», 16 липня 1970 р., Leg. Н.Е. Антонюк (КWHА) (Рис. 2).

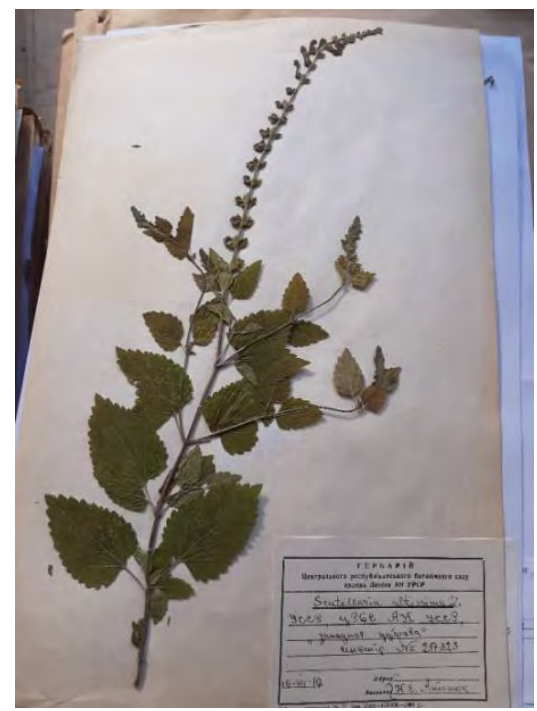

\section{Рис. 2. Гербарії досліджуваних рослин роду Scutellaria L. :S. altissima}

S. baicalensis - багаторічник. Корінь довгий, товстий, м'ясистий, гіллястий. Стебла 15-35 (50) см заввишки, підіймаються або прямостоячі, міцні, прямі або звивисті, прості або від основи гіллясті, голі або коротко волосисті (по ребрах), зелені або часто стають пурпурові (в нижній частині). Листки 1,5-4 см завдовжки, 1,5-13 мм завширшки, від яйцеподібно-ланцетних до лінійно-ланцетних, при основі закруглені або звужені, з тупою або гострою верхівкою, цілокраї, зверху голі або зрідка коротко-волосисті, по краях війчасті, зісподу залозисто-крапково-ямчасті, голі або по середній жилці коротковолосисті, на дуже коротких війчастих черешках або сидячі, щільні, 
майже шкірясті, часто з ледь відігнутими краями. Квітки великі, в простій, однобічній, досить щільній китиці, розташовані по одному в пазухах зменшених (значно менші за квітки) верхівкових листків. Чашечка при квітках приблизно 3 мм завдовжки, зазвичай фіолетового кольору, більш-менш густо-коротко-волосиста, а на верхівці - довговолосиста. Віночок 2-2,5 см завдовжки, синій, ззовні густо-залозистоопушений, трубка його до верху сильно розширена, верхня губа трохи довша за нижню. Цвіте в червні-липні. Зростає на сухих гірських схилах (кам'янисті й глинисті), в степах, у верболозах по берегах річок. Досліджений зразок S. baicalensis: «Читинская обл. Окр. с. Александровского завода $-50^{0} 55^{\prime}$ с. ш. и $117^{0} 55^{\prime}$ в. д. Дол. р. Газимура. ю.-в. склон сопка», 07 липня 1949 p., Leg. H.А. Верховинська й Н.В. Лівтоєв. (КWНА) (Рис. 3).

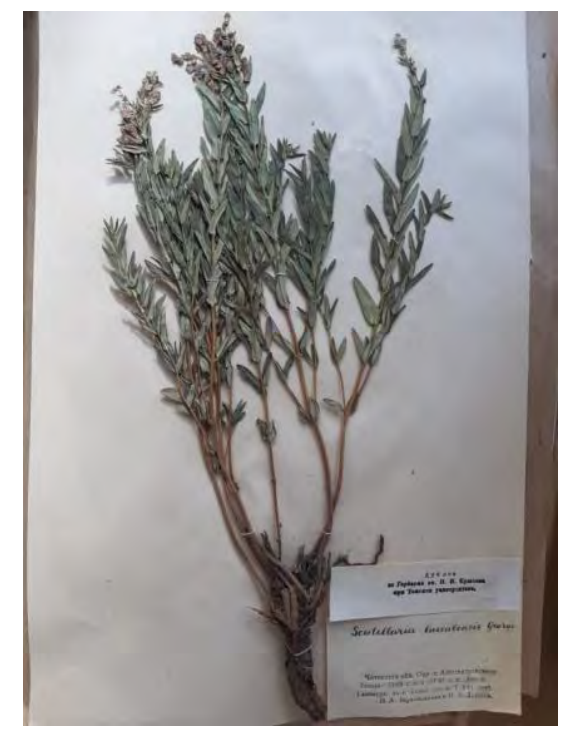

\section{Рис. 3. Гербарії досліджуваних рослин роду Scutellaria L.: S. baicalensis}

S. creticola - напівчагарник із дерев'янистим звивистим і вузлуватим коренем. Стебла численні 10-25 (30) см заввишки, при основі висхідні або рідше майже прямостоячі, вигнуті або злегка звивисті, прості або нерідко гіллясті. Вони вкриті дрібними білими, назад відхиленими, вигнутими волосками по всій довжині (окрім основи), а в суцвітті густо опушені залозистими й короткими відхиленими волосками. Листки 1-3 см завдовжки, 0,3-1,2 см завширшки, яйцеподібні, вузькояйцеподібні або навіть яйцеподібно-ланцетні, при основі здебільшого зрізані, рідше округлі або злегка звужені, по краю неправильно й неглибоко-зубчасті, на верхівці гоструваті й цілокраї. Верхівкові листки нерідко майже по всій довжині цілокраї або з 5-7 зубцями 3 кожного боку. Нижні листки часто з городчасто-округлими на верхівці зубцями. 
Листки зверху голі, зісподу густо залозисто-крапкові, по основнім жилкам дуже дрібно-волосисті. Черешки короткі, в нижніх листків не більше 7 мм завдовжки, в середніх 2-4 мм завдовжки, 3 таким же опушенням, як і на стеблах. Суцвіття спочатку приблизно 2 см завдовжки, густе, згодом до 6 см завдовжки, з пухко розташованими мутовками квіток. Нижні приквіткові листки $1-1,7$ см завдовжки, 0,4-1 см завширшки, яйцеподібні або яйцеподібно-ланцетні, поступово звужені, на верхівці гостроконечні, блідо-зелені, часто лілові, залозисті по краях. Чашечка під час цвітіння приблизно 2 мм завдовжки, густо волосиста й залозиста. Віночок 1,5-2 см завдовжки, жовтий, зовні густо волосистий і залозистий. Цвіте в червні-серпні. Зростає в північносхідній частині України, на крейдяних відслоненнях i схилах. Досліджений зразок S. creticola: «Украина, Луганская обл., Лисичанский p-н., окр. с. Белогоровка, меловые обнажения по р. Сев. Донец», 12 червня 2001 p., Leg. Н. Перегрим, Det. Л.I. Лесняк (KWHA) (Рис. 4).

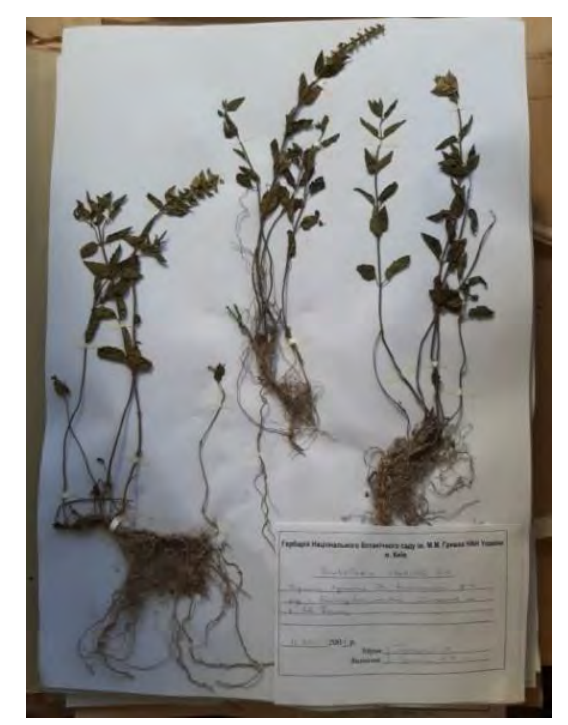

Рис. 4. Гербарії досліджуваних рослин роду Scutellaria L.: S. creticola

\section{2. Карпологічні дослідження}

Оплодень у досліджених видів шкаралупоподібний, крихкий, досить щільно огортає насінину, але не зростається з їі екзотестою. Ереми в дорзальній проєкції округлі, еліптичні чи широкоовальні. В латеральній проєкції видовжені оберненояйцеподібні (як правило, з розширеною верхівкою та звуженою основою), напівкулясті чи неправильно округлі; дорзальна сторона опукла, вентральна плоскіша, часом ввігнута (Рис. 5).

Деякі автори ${ }^{19}$ відзначають в окремих видах розміщення язичкоподібного утворення посередині вентральної сторони. Як показало наше

\footnotetext{
${ }^{19}$ Bojnanský V., Fargašová A. Atlas of Seeds and Fruits of Central and East-European Flora. Springer : Dordrecht, 2007. ISBN 978-1-4020-5361-0 (HB). 1046 p.
} 
дослідження, саме тут розташовується зародковий корінець, який у шоломниць добре розвинений i помітно виступає над поверхнею насінини. Це позначається на структурі оплодня, котрий, піднімаючись над корінцем, утворює широкий язичковий виступ, що простягається від вершини до основи. Довжина й ширина виступу корелюють із розмірами зародкового корінця (Рис. 6).

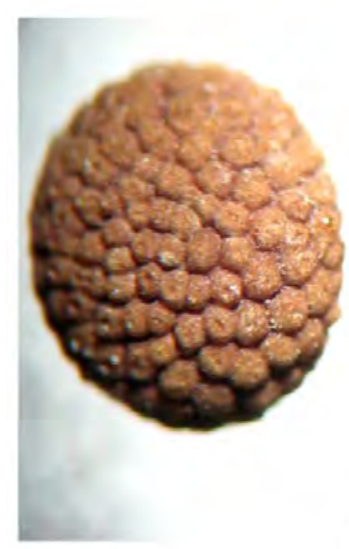

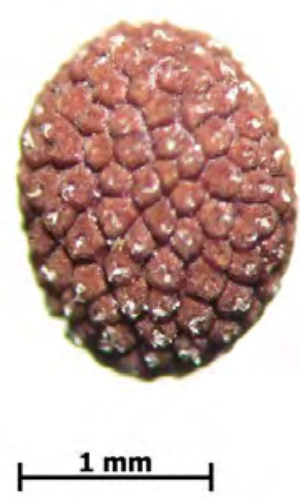

$1 \mathrm{~mm}$

D

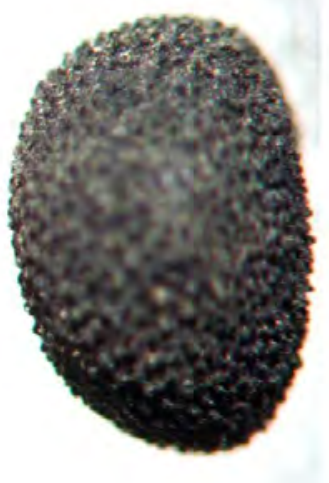

1

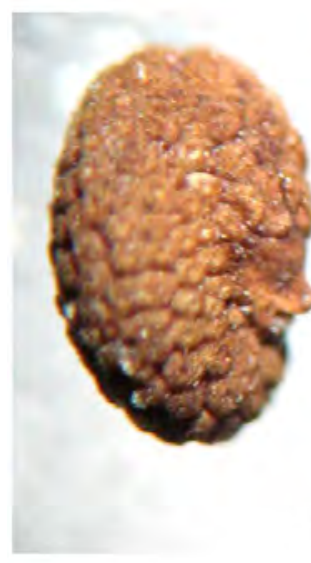

2

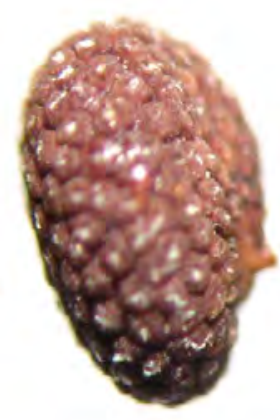

$1 \mathrm{~mm}$
3

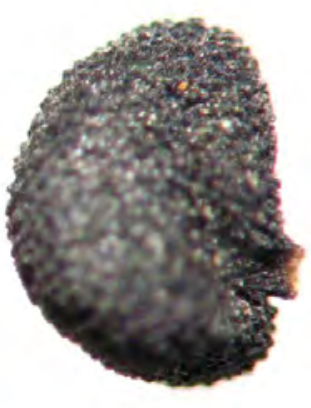

$\mathbf{L}$

Рис. 5. LM. Обриси еремів видів Scutellaria L. із дорзальної (D) та латеральної (L) сторони: 1 - S. altissima; 2 - S. albida; 3 -S. baicalensis

Наявність язичкового виступу в центрі вентральної сторони зумовлює овально-тупо-тригранну проєкцію еремів на поперечному зрізі. Плодовий рубчик вентральний, розміщений на піднятому базальному кінці язичкового виступу, може бути оточений округлим чи підковоподібним м'ясистим валиком, що огортає рубчик з усіх боків. Макрорельєф еремів бородавчастий або горбкуватий, бородавки 
4-8 гранні, з невеликою округлою заглибиною по центру, де розміщені криючі білувато-попелясті напівпрозорі волоски. Горбочки ширококонічні, 3 тупою закругленою верхівкою, ледь здавлені 3 боків. У формуванні бородавчастого й горбкуватого макрорельєфу еремів беруть участь не лише поверхневі шари оплодня (екзокарп), а й глибинні (мезо- й ендокарп). Поверхня опушена або майже гола. Забарвлення від світло- чи рудувато-коричневого до майже чорного. Насіннєва оболонка більш-менш щільно прилягає до оплодня, але не зростається 3 екзокарпом, рудувато-коричнева, плівчаста, досить редукована, без помітної диференціації, що характерно для однонасінних нерозкривних плодів, в яких функції, пов'язані із захистом зародка й розповсюдженням насіння, покладаються переважно на оплодень.
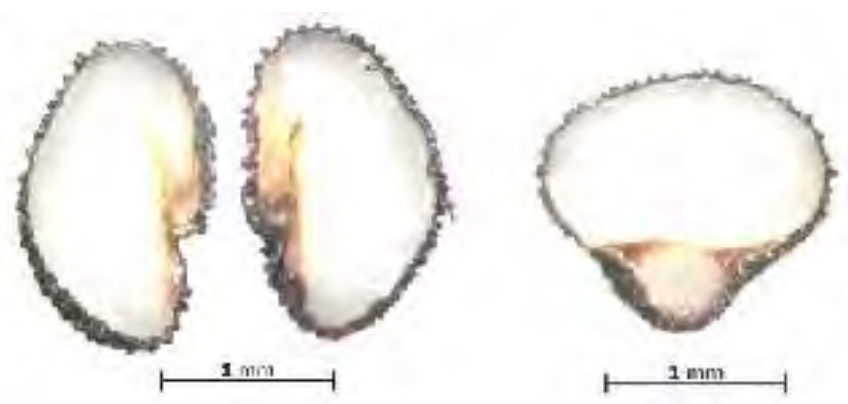

Scutellaria baicalensis
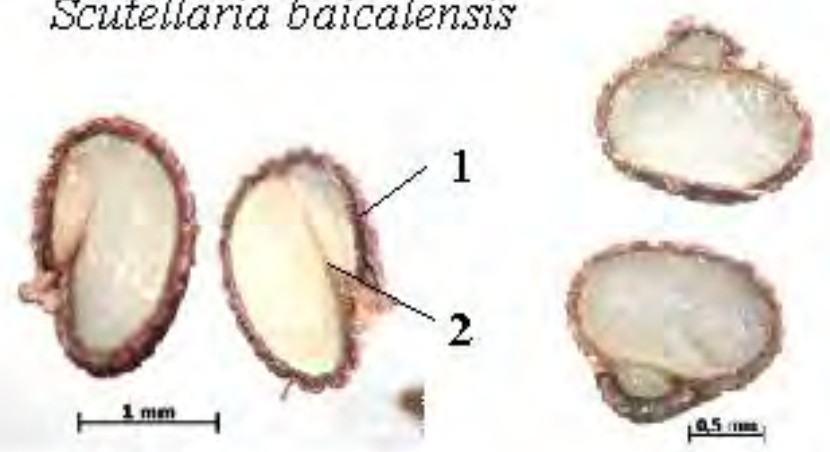

Scutellaria altissima

I

II

Рис. 6. LМ. Поздовжній (I) і поперечний (II) зрізи плодів:

1 - Вентральний язичковий виступ; 2- Зародковий корінець

Під час використання точніших методів дослідження карпологічні відмінності проявляються ще чіткіше. Застосування електронної мікроскопії дозволило детальніше дослідити особливості еремів та уточнити деякі аспекти їх макро- й мікроструктури. Так, у попередніх наших роботах йшлося про опушення $S$. creticola зірчастими 
волосками ${ }^{20}$. На такий же тип опушення видів роду Scutellaria L. вказують В. Божнянський та А. Фаргасова ${ }^{21}$ : "each wart with stelliform, whitish rosette of hairs"22, "Surface densely covered with white, tightly fitting star hairs" 23 . У разі використання світлового мікроскопа зі збільшеннями до х50 разів, яким ми користувались під час попередніх досліджень, опушення справді виглядає зірчастим. Проте електронно-мікроскопічне вивчення чітко вказує, що волоски в заглибинах посередині бородавок не мають спільної базальної клітини й не зрослі між собою, що відзначається зірчастими волосками, а розміщені відокремлено й поодиноко на периклінальних стінках епідермальних клітин екзокарпу. У кожній заглибині може бути від 4-5 до 25 і більше таких волосків, що розташовуються більш-менш щільно у вигляді радіального пучечка, який у разі невеликих збільшень дійсно має зірчастий вигляд. Волоски напівпрозорі, білувато-попелясті, округло-сплющені, прямі чи звивисті.

Ультраструктура поверхні зумовлена особливостями епідерми екзокарпу. Епідермальний шар зберігає клітинну структуру. Клітини епідерми 3 чіткими межами, полігональні, з опуклою периклінальною стінкою, куполоподібні, шатроподібні, видовжено-конічні чи горбкувато-шипуваті. На верхівці клітин по центру периклінальної стінки часто розміщено по одному залозистому напівпрозорому білуватому волоску. Антиклінальні стінки майже прямі, зигзагуваті або звивисті, іноді слабко помітні через щільне розташування значно опуклих епідермальних клітин. У борозенках між бородавчастими виступами оплодня епідермальні клітини з менш опуклою, іноді майже прямою периклінальною стінкою. Кутикулярний шар на поверхні епідерми досить товстий, рівний, хвилястий чи зморшкуватий.

На фоні загального плану будови ереми кожного $з$ досліджених видів мають ряд індивідуальних особливостей (Рис. 7).

S. albida - ереми широкоовальні, ледь сплющені в дорзальновентральній площині, завдовжки 1,38-1,71 мм, завширшки 1,11-1,30 мм, маса 1000 насінин - 1,041 г (Рис. 7). Дорзальна сторона широкоокругла, випукла. Вентральна сторона менш випукла, з язичковим виступом по центру. На верхівці виступ широкий, округлий, слабко окреслений із боків, звужується до основи й сягає половини довжини ерему. На кінці добре помітний випнутий округлий плодовий рубчик, оточений з усіх

\footnotetext{
${ }^{20}$ Vakulenko T., Loya V., Kayutkina T. Diagnostic value of carpological characteristics of Lamiaceae Lindl. Family some species. Conversation of Plant Diversity : Conference International Scientific Symposium. Chişinău, 2017. P. 118.

${ }^{21}$ Bojnanský V., Fargašová A. Atlas of Seeds and Fruits of Central and East-European Flora. Springer : Dordrecht, 2007. ISBN 978-1-4020-5361-0 (HB). 1046 p.

${ }^{22}$ Bojnanský V., Fargašová A. Atlas of Seeds and Fruits of Central and East-European Flora. Springer : Dordrecht, 2007. ISBN 978-1-4020-5361-0 (HB). P. 565.

${ }^{23}$ Bojnanský V., Fargašová A. Atlas of Seeds and Fruits of Central and East-European Flora. Springer : Dordrecht, 2007. ISBN 978-1-4020-5361-0 (HB). P. 567.
} 
сторін підковоподібним рудуватим піднятим валиком із чітко окресленими краями й помірним опушенням звивистими криючими волосками (Рис. 8).
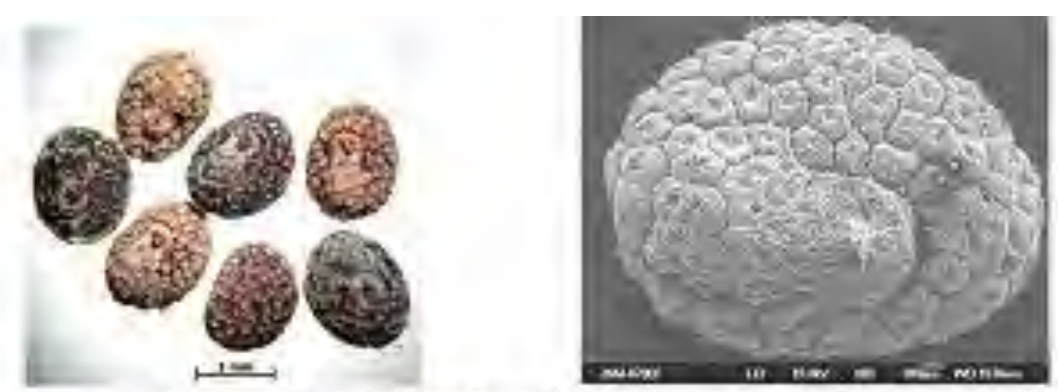

LM Scutellaria albida

SEM
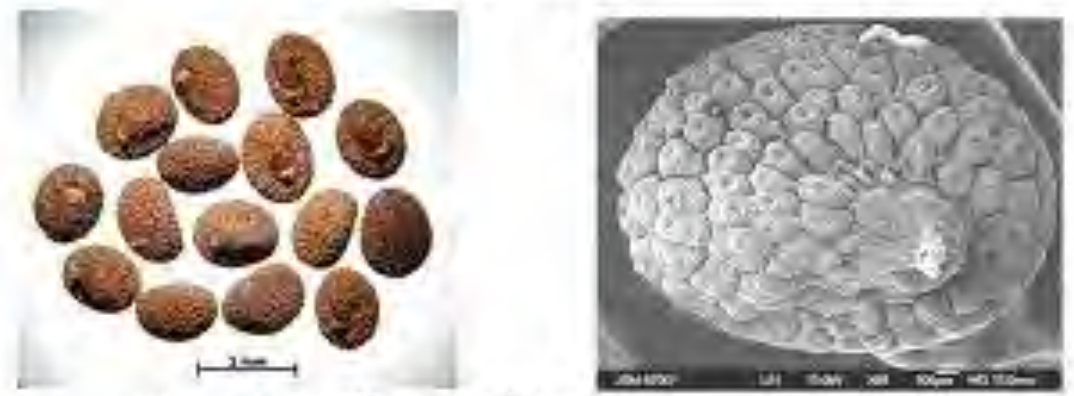

LM Scutellaria altissima

SEM

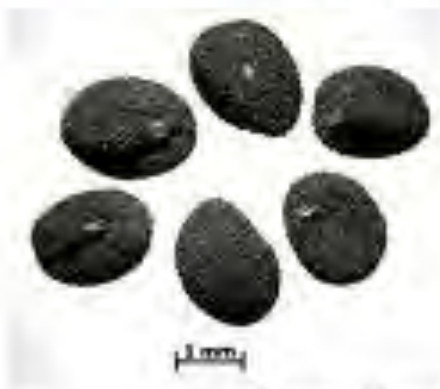

im Scutellaria baicalensis

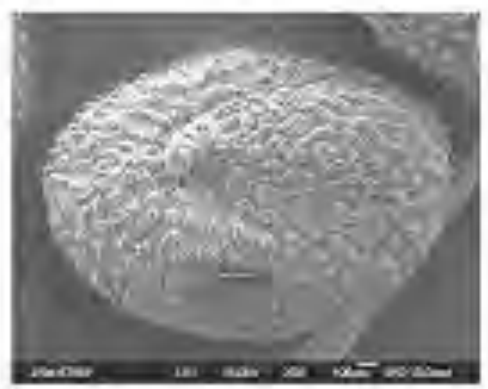

SFM
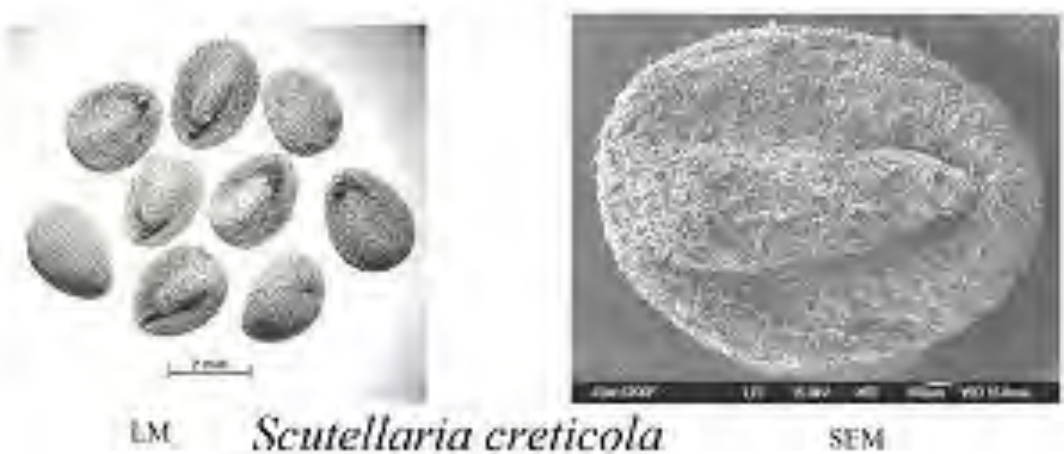

Рис. 7. Загальний вигляд плодів видів роду Scutellaria L.: 1 -S. albida; 2 -S. altissima; 3 - S. baicalensis; 4-S. creticola 

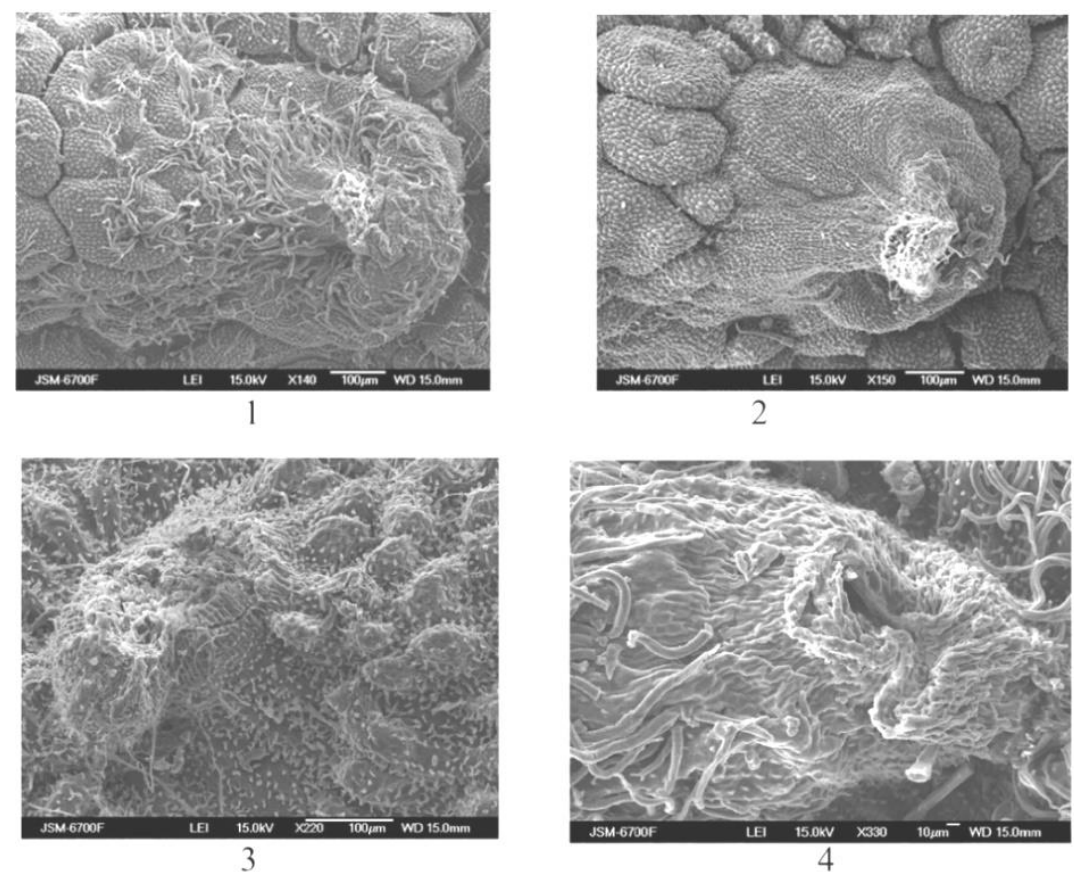

Рис. 8. SEM. Ультраструктура поверхні навколо рубчика: 1 -S. albida; 2 -S. altissima; 3 - S. baicalensis; 4-S. creticola

Поверхня матова, бородавчаста, бородавки плоскуваті, 4-8 гранні, більш-менш ізодіаметричні, $\quad 0,15-0,18 \times 0,20-0,23$ мм, із чіткими контурами, добре відокремлені одна від одної глибокими борозенками (Рис. 9). Опушення помірне, забарвлення від сірувато-коричневого до чорно-коричневого.

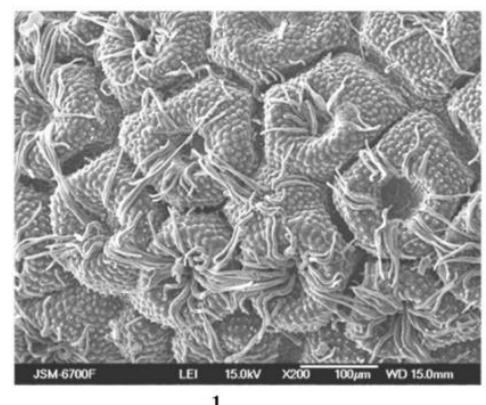

1

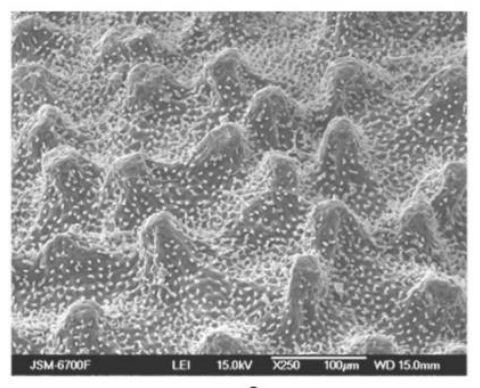

3
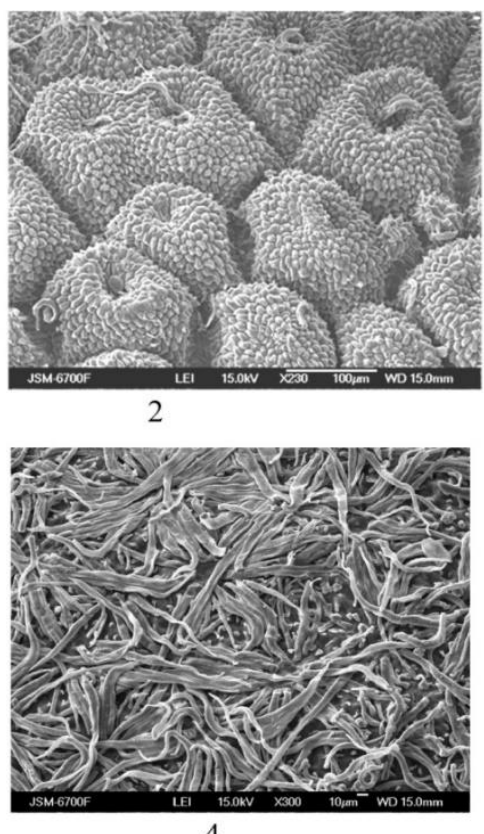

4

Рис. 9. SEM. Рельєф еремів видів роду Scutellaria L.: 1 - S. albida; 2 -S. altissima; 3 -S. baicalensis; 4-S. creticola 
Первинна ультраструктура поверхні характеризується полігональноокруглими, майже ізодіаметричними клітинами епідерми, 7-12 мкм у діаметрі. Антиклінальні стінки прямі, периклінальна опукла, куполоподібна, 3 короткою (2-5 мкм) сосочкоподібною білуватою залозистою трихомою по центру. Заглибини на бородавках глибокі, в діаметрі 40-75 мкм, волосків у заглибинах від 10 до 20, завдовжки 30-60-120 мкм, округлі чи сплющені, зі звуженими кінцями, прямі чи злегка покручені. Вторинна мікроструктура представлена чітко вираженими кутикулярними потовщеннями периклінальних стінок епідермальних клітин, глибоко борозенчаста (Рис. 10).
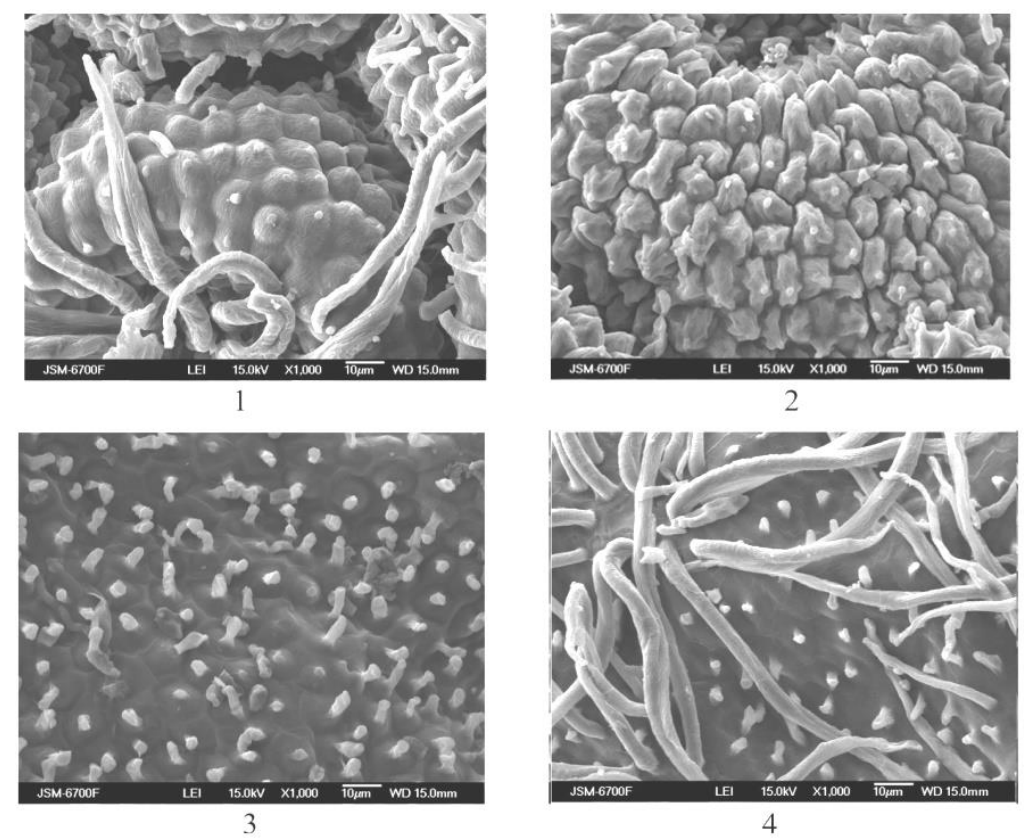

\section{Рис. 10. SEM. Ультраструктура поверхні епідерми видів роду Scutellaria L.: 1 -S. albida; 2 -S. altissima; 3 -S. baicalensis; 4 -S. creticola.}

S. altissima - ереми округлі, завдовжки 1,7-1,93 мм, завширшки 1,31-1,55 мм, маса 1000 насінин - 1,095 г (Рис. 7). Спинка широкоовальна, злегка випукла. Вентральна сторона без виражених граней, ледь опукла, з коротким тупим язичковим виступом, що сягає середини ерему. У верхній частині виступ широкий, плавно згладжений, базальний кінець піднятий, чіткіше окреслений із боків. Плодовий рубчик округлий, випнутий. Підковоподібний валик піднятий, жовтокоричневий, повністю огортає плодовий рубчик, чітко окреслений з усіх сторін, голий, лише кілька криючих волосків зі сторони основи (Рис. 8). Поверхня матова, бородавчаста, бородавки 4-5-8-гранні, на спинці майже ізодіаметричні, $0,22-0,25 \times 0,24-0,27$ мкм, на черевці навколо 
рубчика видовженіші, 0,24-0,25x0,31-0,34 мкм (Рис. 9). Опушення ледь помітне, забарвлення рудувате чи світло-коричневе.

Первинна ультраструктура представлена полігональними видовженими щільно розміщеними клітинами епідерми, 5-7x10-12 мкм. Антиклінальні стінки зигзагуваті, периклінальні значно опуклі, часто здавлені, шипувато-горбкуваті. Заглибини на бородавках оплодня округлі, неглибокі, діаметром 35-55 мкм, з 1-5 криючими плоскуватими волосками завдовжки 75-80 мкм, окремі бородавки без волосків. Залозисті трихоми на периклінальних поверхнях епідермальних клітин короткі, 2-5 мкм, сосочкоподібні, в деяких клітин відсутні. Вторинна ультраструктура добре виражена, хвиляста, місцями хвилясто-сітчаста, кутикулярний покрив без нашарувань (Рис. 10).

S. baicalensis - ереми овальні, видовжені, до основи тупо тригранні, завдовжки 1.5-2.1 мм, завширшки 1.4-1.6 мм, маса 1000 насінин 0,775 г (Рис. 7). Дорзальна сторона значно випукла, вершина широко округла. Вентральна сторона майже пряма. Язичковий виступ над зародковим корінцем округлий, на вершині розширений, донизу звужений, окреслений із боків неглибокою борозенкою, базальний кінець піднятий, 3 округло-здавленим сіруватим ледь заглибленим плодовим рубчиком, без вираженого підковоподібного валика (Рис. 8). Поверхня гола, матова, горбкувата, горбочки у вигляді широких конічних папіл із закругленою верхівкою, заввишки 34,2-52,4 мкм, завширшки при основі 37,5-63,2 мкм (Рис. 9). Забарвлення чорне.

Первинна ультраструктура зумовлена полігональними ізодіаметричними (8-10-15 мкм у діаметрі) клітинами епідерми екзокарпу. Антиклінальні стінки клітин потовщені, прямі. Периклінальні ледь опуклі, шатроподібні, з видовженою до 8-5 мкм білуватою циліндричноконічною залозистою трихомою 3 добре помітною головкою. Крізь скупчення залозок зрідка проглядаються поодинокі криючі волоски, що не впливають на загальне опушення ерему. Вторинна ультраструктура виражена слабко, дистальна частина периклінальних стінок гладенька, лише в проксимальній навколо залозок ледь помітні невеликі радіально розташовані складочки (Рис. 10).

S. creticola - ереми оберненояйцеподібні, завдовжки 1,34-1,77 мм, завширшки 1,13-1,27 мм, маса 1000 насінин - 0,463 г (Рис. 7). Верхівка широкоокругла, дорзальна сторона опукла, вентральна - ввігнута, посередині з округлим язичковим виступом, що тягнеться вздовж ерему від верхівки майже до основи. Виступ розширений в апікальній частині плоду, в базальній - трохи звужений, із боків по всій довжині чітко окреслений глибокими борозенками. Плодовий рубчик розташований на базальному кінці виступу, слабко помітний, округлий, заглиблений, світлий, із тонким темним обідком (Рис. 8). Поверхня щільно опушена 
білувато-попелястими криючими волосками. Завдяки такому повстяному опушенню забарвлення еремів видається сріблясто-сірим.

Первинна ультраструктура поверхні лише подекуди проглядається крізь повстяне опушення, сформована видовженими (10-15x8-12 мкм) полігональними клітинами епідерми екзокарпу. Антиклінальні стінки тонкі, злегка звивисті. Периклінальні стінки в дистальній частині рівні, в проксимальній - ледь опуклі, рідше ввігнуті, 3 короткою (3-5 мкм) сосочкоподібною залозистою трихомою на верхівці. Поверхня оплодня слабко горбкувата, без виражених заглиблень (Рис. 9). Криючі волоски пласкі чи округлі, 80-120 мкм завдовжки, розташовуються радіальними пучечками по 15-25 штук, часто злиплі й переплетені між собою. Вторинна ультраструктура не виражена, кутикулярний шар майже гладенький (Рис. 10).

Дослідження показали, що ереми видів Scutellaria L характеризуються значною різноманітністю макро- й мікроструктури. В результаті аналізу оригінальних матеріалів виявлено комплекс діагностичних ознак, що мають важливе значення під час розмежування видів. За формою ереми видовжено чи широкоовальні ( $S$. albida, S. baicalensis), оберненояйцеподібні $(S$. creticola) чи округлі $(S$. altissima). Види чітко розрізняються за характером макрорельєфу оплодня: бородавчастий (S. albida, S. altissima) й горбкуватий (S. baicalensis, $S$. creticola). Вентральний язичковий виступ над зародковим корінцем виявлено у всіх досліджених видів, проте лише в $S$. creticola він сягає майже основи ерему, чітко окреслений із боків по всій довжині; в інших видів коротший, окреслений лише на кінці, у верхній частині згладжений. Підковоподібний валик навколо плодового рубчика добре виражений у S. albida й S. altissima; водночас він може бути голий (S. altissima) або опушений (S. albida). У S. baicalensis i $S$. creticola валик не виражений. Макрорельєф еремів зумовлений характером поверхні оплодня та ступенем його опушення. У S. albida й S. altissima рельєф утворений великими бородавчастими виступами оплодня. Для $S$. baicalensis $i$ S. creticola характерна горбкувата поверхня оплодня. Щільним повстяним опушенням криючими волосками відрізняється $S$. creticola, в решти видів опушення криючими волосками незначне або майже відсутне (S. baicalensis).

Застосування електронної мікроскопії виявило ряд додаткових карпологічних ознак первинної та вторинної ультраструктури. На рівні первинної ультраструктури клітини епідерми екзокарпу досліджених видів полігональні, із чітким межами, ізодіаметричні ( $S$. albida, S. baicalensis) чи видовжені (S. altissima, S. creticola). Антиклінальні стінки прямі (S. albida, S. baicalensis), зигзагуваті (S. altissima) чи хвилясті (S. creticola). Периклінальна стінка епідермальних клітин 
більш-менш опукла, в S. albida - куполоподібна, в S. baicalensis шатроподібна, в S. altissima - шипувата. У S. creticola периклінальні стінки ледь опуклі лише в проксимальній частині, в дистальній - майже рівні, іноді навіть ввігнуті. Опушення сосочкоподібними залозистими трихомами, що розміщені на верхівках епідермальних клітин, загалом помірне. Лише в S. baicalensis за майже повної відсутності криючих волосків видовжені залозисті трихоми утворюють досить значне опушення, проте добре помітне воно лише при великих (від х200) збільшеннях. Виявлено суттєві відмінності в рельєфі поверхні підковоподібного валика, що оточує плодовий рубчик. На ньому відсутні бородавки чи горбочки, в утворенні яких залучені всі шари оплодня (екзо-, мезо- й ендокарп). Рельєф зумовлений первинною ультраструктурою поверхні й сформований щільними, майже паралельними рядами здавлених із боків епідермальних клітин, переважно без залозистих трихом, що радіально розташовуються навколо плодового рубчика.

Вторинна ультраструктура поверхні еремів, що зумовлена характером кутикулярних відкладень, добре виражена в S. albida (борозенчаста) й S. altissima (хвиляста). У S. baicalensis радіально-складчаста вторинна ультраструктура виражена слабко, лише на верхівці епідермальних клітин навкруги залозок. Для S. creticola характерний майже гладенький кутикулярний шар, вторинна ультраструктура не виражена.

\section{ВИСНОВКИ}

Проаналізовано видову різноманітність роду Scutellaria L., визначено перспективи поповнення видового складу інтродуцентами світової флори 3 метою їх різнопланового використання. Наведено ботанічний опис досліджуваних видів, який співставний із наявними гербарними зразками.

Комплекс виявлених і проаналізованих ознак та особливостей макрой мікроструктури ілюструє структурну різноманітність чотирьох досліджених видів Scutellaria L. Ереми характеризуються як спільними, так і відмінними ознаками. До спільних ознак належать: наявність вентрального язичкового виступу, утвореного над місцем розташування зародкового корінця насінини; базальне положення плодового рубчика на кінці язичкового виступу; полігональна форма епідермальних клітин екзокарпу, межі яких чітко проглядаються. Ці ознаки можуть бути додатковими діагностичними на рівні роду.

До відмінних ознак належать: форма еремів; тип рельєфу оплодня (бородавчастий чи горбкуватий); наявність i характер опушення; щільність криючих волосків, розміщених пучечками в заглибинах 
бородавок; рівень опуклості периклінальних стінок клітин епідерми. Ці ознаки належить використовувати як діагностичні на видовому рівні.

Встановлено, що первинна ультраструктура еремів зумовлена формою клітин епідерми екзокарпу, конфігурацією антиклінальних i периклінальних стінок, наявністю та щільністю опушення, утвореного переважно криючими волосками, рідше - залозистими.

Вторинна ультраструктура визначається характером і ступенем вираженості кутикулярного шару на поверхні екзокарпу. Особливості вторинної скульптури поверхні, сформовані відкладеннями кутикули, визначають тонкий рельєф зовнішніх клітинних стінок і також мають таксономічне значення під час розмежування видів.

Уточнено, що повстяне опушення еремів забезпечують не зірчасті волоски, як вважалось раніше, а прості криючі волоски, що розміщуються радіально в пучечках.

Отримані дані можуть бути використані для розв'язання спірних питань систематики, сприяють встановленню закономірностей спеціалізації насінних покривів не тільки роду Scutellaria L, а й родини Lamiaceae в цілому. Отримані матеріали оригінальні й можуть бути використані для оптимізації методик порівняльно-морфологічного дослідження, а також опису макро- й мікроструктури плодів і насіння.

\section{АНОТАЦІЯ}

Види роду Scutellaria L. становлять інтерес для широкого кола фахівців: ботаніків, фармакологів, квітникарів тощо. Проаналізовано видову різноманітність роду. Серед досліджених видів роду Scutellaria L. три види входять до складу природної флори України, один вид - до складу далекосхідної флори, але широко культивується в Україні. Карпологічне дослідження чотирьох видів роду Scutellaria L. показало, що їх плоди характеризуються як спільними, так і відмінними ознаками. До спільних ознак належать: наявність вентрального язичкового виступу, утвореного над місцем розташування зародкового корінця насінини; базальне положення плодового рубчика на кінці язичкового виступу; полігональна форма епідермальних клітин екзокарпу. Ці ознаки можуть бути додатковими діагностичними на рівні роду. До відмінних ознак належать: форма плодів; тип рельєфу оплодня; наявність і щільність його опушення; рівень опуклості периклінальних стінок клітин епідерми. Перелічені ознаки слід використовувати як діагностичні на видовому рівні. Встановлено, що первинна ультраструктура плодів зумовлена формою клітин епідерми екзокарпу, конфігурацією антиклінальних i периклінальних стінок, наявністю та щільністю опушення, утвореного залозистими чи криючими волосками. Вторинна ультраструктура визначається характером і ступенем вираженості кутикулярного шару на 
поверхні екзокарпу. Уточнено, що повстяне опушення плодів забезпечують не зірчасті волоски, як вважалося раніше, а прості криючі волоски, що розміщуються радіально в пучечках.

\section{ЛIТЕРАТУРА}

1. Джуренко H.I. Оцінка генетичних ресурсів колекційного фонду лікарських рослин. Фактори експериментальної еволюції організмів / Н.І. Джуренко, О.П. Паламарчук, С.О. Четверня, І.В. Коваль. 2019. Т. 24. C. 254-258. DOI: https://doi.org/10.7124/FEEO.v24.1111.

2. Флора СССР Т. 20 / ред. Б.К. Шишкин, С.В. Юзепчук. МоскваЛенинград : Из-во Академии наук СССР, 1954. С. 71-225.

3. Определитель высших растений Украины / Д.Н. Доброчаева, М.И. Котов, Ю.Н. Прокудин и др. 1 изд. стереот. Киев : Фитосоциоцентр, 1999. $548 \mathrm{c}$.

4. Ranjba M., Mahmoudi C. Chromosome numbers and biogeography of the genus Scutellaria L. (Lamiaceae). Caryologia. No. 66. 2013. P. 205-214. DOI: $10.1080 / 00087114.2013 .821840$.

5. Мінарченко В.М. Лікарські судинні рослини України (медичне та ресурсне значення) : монографія. Київ : Фітосоціоцентр, 2005. С. 211.

6. Державна фармакопея України. URL: https:// www.pharmencyclopedia.com.ua/article/2462/derzhavna-farmakopeya-ukraini.

7. Патентный поиск в PФ. URL: http://www.freepatent.ru/patents/ 2121357.

8. The Sloan Kettering Institute (SKI). URL: https://www.mskcc.org/ cancer-care/integrative-medicine/herbs/scutellaria-baicalensis.

9. Дудецкая Н.А. Фармакогностическое изучение травы шлемника обыкновенного Scutellaria galericulata L. : автореф. дисс. ... канд. фарм. наук : 14.04.02 «Фармацевтическая химия, фармакогнозия»; ГБОУ ВПО Санкт-Петербург гос. хим.-фарм. академия Минздравсоцразвития России. Санкт-Петербург, 2011. 20 с.

10. Каден Н.Н. Основы эволюционной морфологии плодов : дис. ... д-ра биол. наук. Москва : 1964. 676 с.

11. Левина Р.Е. Репродуктивная биология семенных растений : обзор проблемы. Москва : Наука, 1981.96 с.

12. Меликян А.П., Бобров А.В., Романов М.С. Морфогенез плодов Magnoliophyta. Москва : URSS, 2008. 317 c.

13. Takhtajan A.I. Diversity and classification of flowering plants. New York : Columbia University Press, 1997. 643 p.

14. Футорна О.А., Жигалова С.Л. Ультраструктура поверхні насінин видів роду Gladiolus L. (Iridaceae Juss.) флори України. Чорноморський ботанічний журнал. 2014. № 10 (1). C. 15-25. DOI: 10.14255/2308$9628 / 14.101 / 2$. 
15. Червона книга України. Рослинний світ / під заг. ред. Я.П. Дідуха. Київ : Глобалконсалтинг, 2009. 912 с.

16. Артюшенко 3.Т., Федоров А.А. Атлас по описательной морфологии высших растений. Плод. Ленинград : Наука, 1986. 392 с.

17. Barthlott W. Epidermal and seed surface characters of plants: systematic applicability and some evolutionary aspects. Nord. J. Bot. 1981. No. 1 (3). P. 345-355.

18. Stern W.T. Botanical Latin. Oxford, 1992. 612 p.

19. Bojnanský V., Fargašová A. Atlas of Seeds and Fruits of Central and East-European Flora. Springer : Dordrecht, 2007. ISBN 978-1-4020-5361-0 (HB). $1046 \mathrm{p}$.

20. Vakulenko T., Loya V., Kayutkina T. Diagnostic value of carpological characteristics of Lamiaceae Lindl. Family some species. Conversation of Plant Diversity : Conference International Scientific Symposium. Chişinău, 2017. P. 118.

\section{Information about authors:} Koval I. V., Candidate of Biological Sciences, Senior Researcher M. M. Gryshko National Botanical Garden of the National Academy of Sciences of Ukraine

1, Timirjazewska str., Kyiv, 01014, Ukraine Vakulenko T. B., Candidate of Biological Sciences, Senior Researcher

M. M. Gryshko National Botanical Garden of the National Academy of Sciences of Ukraine, 1, Timirjazewska str., Kyiv, 01014, Ukraine 